\title{
ABDULLAH AVLONI'S CONTRIBUTION TO RAISING CHILDREN
}

\author{
Ibrohimova Mohizar
}

Senior teacher Student of ASU, Uzbekistan

\section{ABSTRACT}

This article reveals the pedagogical heritage of Abdullah Avloni. The works of the educator in the field of education are named.

KEYWORDS: - Teaching, upbringing, heritage, pedagogy, education, youth, spirituality, enlightenment.

\section{INTRODUCTION}

The people of Uzbekistan have made a significant contribution to the development of world culture and education. Among the outstanding figures of the centuries-old Uzbek culture, such scientists as Al-Khorezmi, Al-Farabi, Ibn Sino, Beruni, Naqshbandi, Mirzo Ulugbek and others occupy a worthy place. The ideas of great thinkers and progressive teachers put forward a critical study of the development of pedagogical science and the enrichment of history. One such great thinker and teacher was Abdullah Avloni. Abdullah Avloni is a well-known Uzbek writer who wrote for children, playwright, educator and teacher, contributed to the development of the modern Uzbek school. He was born in 1878 in Tashkent. He studied at the madrasah. Abdullah Avloni was one of the founders of new methodology schools for Uzbek children. He also wrote textbooks and manuals for these schools.
In 1907 he

published the newspaper "Shukhrat" in the Uzbek language. Also A. Avloni organized the bottom of the first Uzbek theater troupes in Tashkent at the end of 1913, called "Turkestan", which existed until February 1917.

In 1908 he opened a new methodology school in Mirabad. The opening of such schools made it possible to teach the children of the local population to read and write, to form a new outlook in them. Together with the basics of Islam, these schools taught arithmetic, history, geography and natural history. And also in the classroom, teachers tried to acquaint their students with the achievements of the East and West. He was one of the most active educators in Uzbekistan during the Soviet period. He taught and wrote books, plays for the Uzbek theater.

From 1909 to 1917, he wrote more than 10 textbooks, which played a crucial role in the history of the Uzbek school and the development 
CURRENT RESEARCH JOURNAL OF HISTORY 2(10): 01-02, October 2021

DOI: https://doi.org/10.37547/history-crjh-02-10-01

ISSN 2767-472X

(C)2021 Master Journals

\section{Crossref dof 81 Google}

Accepted 05th October, 2021 \& Published 10th October, 2021

of pedagogical thought. Pedagogy has been raised to a new level. His book "The First Teacher" was intended for elementary school and adhered to the principles: from simple to complex. The book "The Second Teacher" was a development and continuation of the first book.

In 1917, the book "Turkic Flower Garden or Morality" was published, in which Avloni expounds his social, moral and educational views. In creating it, he relied on folk pedagogy. He believed that education begins at birth and continues until the end of life. Upbringing is the responsibility of parents, teacher, mentor and state. Avloni also attached great importance to talent, breadth of outlook, education, personality of the teacher. The strength and breadth of the student's thinking depends on the width of the teacher's views. The book pays great attention to the issues of patriotism. Avloni believed that the Motherland «... you can't just love, you need to be proud of it. Love should be expressed directly in deeds and the desire to make their homeland more perfect. The homeland is sacred like a mother». He devoted a whole chapter to his native language and literature. Avloni writes that language and literature is an indicator of the existence of every nation on earth. Abdullah Avlony called for the preservation and preservation of the purity of the native language. The book is divided into two parts: this is a description of the good and bad qualities. 18 chapters are devoted to the description of bad qualities. Above all Avloni put the freedom of the homeland. Knowledge and enlightenment is the only path that could lead to it. This book left a big mark on the development of pedagogy at the beginning of the twentieth century and on the development of social and aesthetic thinking of the younger generation. Abdullah Avlony made a huge contribution to the Jadid movement, it was thanks to his works that the world became acquainted with the Jadid Uzbek literature.
In 1925-1930 at the Central Asian University, he served as head of the department of "language and literature." (1, p.99).

Abdullah Avloni died on August 25, 1934 in Tashkent and was buried at the Botkin cemetery.

Everything that the great teacher of the Uzbek people wrote about is still relevant now, in the age of information and communication technologies, when every student must understand the role of education in his life.

\section{REFERENCES}

1. History of pedagogy / Authors-comp. S.A. Madyarova, R.M. Medetova et al. Tashkent: TSPU, 2020

2. Reflections on the problems of education in modern schools. St. Petersburg 2011.

3. Obutov E. E., Lavrova V. P. Problems of education of the younger generation in modern conditions // Scientific and methodological electronic journal "Concept". - 2016. 